\title{
Pell Grants for Prisoners Part Deux: It's Déjà Vu All Over Again J. M. Taylor
}

Derhaps the most asinine amendment to the already mulish United States Omnibus Crime Bill (Currie, 1994) was submitted by Senator Kay Bailey Hutchison (R-TX) three days before the Senate overwhelmingly approved H.R. 3355. On November 16, 1993, the junior senator from Texas stood before the most exclusive millionaires' club in the world and lamented that prisoners serving sentences "for offenses like carjacking, armed robbery, rape and arson received as much as $\$ 200$ million in Pell [higher education] funds, courtesy of the American taxpayer" (Congressional Record - Senate, 1993). She explained to the august assembly that although the year before they had approved the Higher Education Reauthorization Act (HERA), which in part stipulated that prisoners serving death and life without parole sentences were prohibited from receiving Pell Grants, the current reduced prisoner eligibility was still "not right." Thus the senator's solution was to prohibit all state and federal prisoners from receiving Pell higher education grants.

The senator was not alone in her discontent, nor the only legislator moved to action. Three weeks before, waving a copy of the Pottstown, PA Mercury above his head, Representative Timothy Holden from Pennsylvania fulminated before the C-SPAN cameras that he was appalled to learn from the newspaper's report that prisoners were receiving $\$ 200$ million in Pell Grant funding, allowing them free college educations (Berkey, 1993A). "There is an obligation to do the best you can to give incarcerated people a chance, but certainly not from a program that has been earmarked for low-income people to educate their children," explained the representative. This, he argued, was "an outright abuse" (Berkey, 1993A).

The abuse the congressman referred to, besides the fact that prisoners were receiving this grant, was that colleges listed bogus students, inflated tuition bills, and submitted fraudulent housing charges for already "housed" prisoner-students. He also accused the understaffed office administering the grant program of negligence. Holden then declared that he was planning to co-sponsor Representative Bart Gordon's (D-TN) Amendment 1168, which would exclude prisoners from Pell Grant eligibility. At the conclusion of his speech, the congress- 
man was barraged by other House members questioning him about his proposal.

In the immortal words of that great uniquely American philosopher, Yogi Berra, "It's Déjà Vu all over again." Over three years before the Hutchinson Amendment, Senator Jesse Helms (R-NC) initiated what became an annual Capitol Hill exclusion-fest to effectively eliminate prisoners' post-secondary opportunities. In early 1992, Representative Thomas Coleman (R-MO) and Bart Gordon (D-TN) introduced a joint resolution (1168) that would prohibit, "any individual who is incarcerated in any Federal or State penal institution" from qualifying for Pell Grant funding (Congressional Record - House, 1992A).

Both the Senate and House proposals were eventually defeated after extensive, though low-keyed lobbying in committee hearings (Taylor, 1993A). In the spring of 1993, Gordon (sans Coleman) reintroduced H.R. 1168 , only to see it languish and fade away in committee backwaters during the session, never to see a floor vote (Taylor, 1993B). Gordon, obviously a politician not to be deterred by failure or facts, resubmitted his Amendment for a third time, with it so sensationally spotlighted by Congressman Holden. Finally, on April 20, 1994, the day after the broadcast of a highly biased and inflamatory report on the topic by the news magazine Dateline NBC (Taylor, 1994), the House (in a vote of 312 to 116) added its own expulsion amendment to the crime bill. When President Bill Clinton signed the Crime Bill in September 1994, prisoners became ineligible for Pell Grant disbursements.

What was lost in all the smoke and mirrors of the grandstanding rhetoric was the purpose of the Pell Grant program, the very real crime fighting effectiveness of higher education. Coleman, Gordon, Helms and others who supported Gordon's amendment used specious reasoning and disingenuous pronouncements which culminated in descriptions of dire predicament that bore no resemblance to reality.

Senator Hutchinson (1994) rationalized her proposal for citing the federal government's expenditure of $\$ 100$ million a year on education and training available only to prisoners. She stated that the Pell Grant program was created, "in order to help the children of the poor and working class families to have a chance to go to college" (Congressional Record - Senate, 1993), and that more than one million students were denied grants because there was not enough money to go around. To punctuate the point of this ongoing injustice, she used the example of an 
exasperated police officer whose daughter could not qualify for a Pell Grant. The Senator quoted his trite retort that, "maybe I should take off my badge and rob a store" (Congressional Record - Senate, 1993).

To begin with, the Senator was a few dollars off in her claim of the amount the federal government spends on prisoner education and training. The Department of Education's Office of Correctional Education, which coordinates the dispersal of federal dollars to state correctional systems, reports that less than $\$ 70$ million is passed on to educate prisoners (Schwartz and Koch, 1992). In addition most of these federal correctional education funds are dollars dedicated to particular literacy and adult basic education opportunities such as the G.E.D. program, allowing administrators limited discretion in how to spend them. Less than six percent ( $\$ 1.3$ billion) is spent on offender education, vocational training, substance abuse counselling and programs of all types (Lillis, 1993a). With this amount of funding, it should come as no surprise that the median education of those paroled in 1990 was at the $10^{\text {th }}$ grade level (Perkins, 1993), while 70 percent of prisoners have drug problems (Krammer, 1993). One state (Nevada) even reported no educational budget item at all (Lillis, 1993a).

For years, educators have noted that there has been and continues to be considerable need for improvement in correctional education programs (Quay, 1973; Partlett, 1981; Rousch, 1983; Corcoran, 1985; O'Neil, 1990). National surveys (Bell, et al., 1979; Conrad, 1981; Hovarth, 1983; Ryan and Woodard, 1987; Lillis, 1994) have all found that the major problem facing correctional education programs was the lack of funding. By 1993, Jamie Lillis, a research assistant for the Corrections Compendium, noted that "budget cuts continue to whittle away at the quality and perhaps even the very existence of many education and training programs for incarcerated offenders"(1993b). With only 15 percent of the adult prison population enrolled in formal education programming and three times as many eligible (Lillis, 1994), it is a fallacious assumption by the senator that correctional education is already adequately supported in the United States.

In 1968, when Congress created the Basic Education Opportunity Grant program, later called Pell Grants in honor of Senator Claiborne Pell (D-RI) who sponsored the legislation, the purpose was to assist the poor and working class to have a chance to finance a college education. This goal has been (and still is) being largely achieved. In 1993-94, 70 
percent of the Pell Grants went to students from families who earned less than $\$ 15,000$, with 95 percent of the grants going to those whose families earned less than $\$ 30,000$ yearly (Congressional Record - Senate, 1993). Reversing the Bush administration's policy of pushing eligibility levels ever lower (Toch and Slafsky, 1991), Congress began in 1992 to expand the program's parameters to include more middle class families by raising the maximum family income ceiling from $\$ 33,000$ to $\$ 42,000$ (Krauss, 1992). By the 1993-94 academic year, over 4.3 million students received $\$ 6.4$ billion in Pell Grant disbursements (Berkey, 1993b; Berkey 1993c).

Even with this level of funding, over a million students were denied Pell Grant assistance in 1994. The short-fall in assistance was a result of a combination of inflation, overall reduced aid, and swollen enrollments. Between 1980 and 1990, the annual tuition at a four-year public university rose a whopping 141 percent, and tuition at private colleges rose even higher (The Washington Spectator, 1992). The cost of higher education, as a share of median family income rose from 12 to 16 percent of the family budget when the student attended a public shool and to nearly 40 percent up from 26 percent when the student attended a private institution. Yet as tuition increases surpassed those of even the much vaunted medical inflation rate, state and federal financial assistance increased by only 50 percent, barely covering more than a third of the ballooning costs (Wagner, 1993). Combine the two factors of tuition inflation and relative aid reductions with the 34 percent jump in college enrollments beginning at the start of the recession in 1991 (Berstein, 1993a), and you have a national enrollment of 14 million students (Berstein, 1993b) many of whom and their families struggle to pay tuition bills. Since four out of five American families' real income declined during the 1980s (Sanders, 1993), with full-time working families of four existing below the poverty line growing from 12 to 18 percent of the population (Hitchens, 1993), the crunch to give junior or daughter (God forbid, both!) a college education has never been greater.

A significant point omitted by the promoters of the exclusionary legislation is that every student applicant to the Pell Grant program that qualifies receives a grant. The yearly Congressional appropriation, which has never been enough to fulfill the program's established spending parameters, is divided on a sliding, need-based scale amongst those who receive grants. Therefore, not a single Pell Grant qualified student 
has ever been denied a Pell Grant because a prisoner received one. With the elimination of prisoners from the Pell Grant program not a single additional student will receive a grant, but rather the funds that had gone to eligibile prisoner-students will be distributed amongst the rest of the millions of recipients. If evenly disbursed, this means that grant recipients in 1995 received less than an additional $\$ 5.00$ a semester, while some 30,000 prisoner-students were no longer able to go to school (Sullivan, 1994).

In Who Goes To Prison?, the researchers reported that 65 percent of prisoners had not completed high school. A like number had no specific job skills, and half had never been employed. A national survey a decade ago defined between three to four-fifths of the prison population as functionally illiterate (Bell et al., 1984). All the while, Workforce 2000 observes that the majority of new jobs will require a skilled and college educated workforce, with the majority of this labour pool to be drawn from female and minority populations. With their gross lack of educational attainment, 60 percent of the prison population composed of minorities (Stephan, 1992), and 70 percent having existed below the poverty line the year preceding their incarceration (Perkins, 1993), does the question that prisoners are needy or deserving students even need to be asked?

It seems evident that even with the inclusion of prisoners the Pell Grant program is fulfilling its stated objective; assisting the poor and working class to finance a college education. This is especially so when considering the opinions of those voting for the Higher Education Reauthorization Act, who represent a wide range on the political spectrum. "One of the central goals of this legislation was," thought to be by Senator Edward Kennedy (D-MA), "to increase access to higher education for all Americans" (Congressional Record - Senate, 1992). Senator David Durenburger (D-MN) observed that "we do need to make higher education more accessible for every American student. And we do need to be accomodating to the changing nature of the student population" (Congressional Record - Senate, 1992). On the far right, Senator Phil Graham (R-TX), Hutchinson's senior, stated that "ensuring access to higher education for all segments of society helps to equalize opportu- 
nities for all people to pursue and achieve the American dream (Congressional Record - Senate, 1992)."

Senator Hutchinson's lamentation over the one million applicants who were denied grants is a specious point. The already noted economic and demographic impact of double-digit tuition inflation, single digit aid increases, and exploding enrollments coupled with families' shrinking real incomes, places a strain on an admittedly wallowing bureaucracy (Associated Press, 1992). Additionally, those "denied" assistance did not qualify for it in the first place. As a matter of due course, financial aid counselors advise students to apply for anything and everything possible, and then use the evaluative reports to assist in their own aid disbursement decisions. Furthermore, in the 1994-95 academic year, an additional 324,000 grants were awarded, totalling 4.7 million students (over onequarter of the national collegiate enrollment) helped by the Pell Grant program (Berkey, 1993c).

Finally, the dramatically quoted police officer's frustration is a little disingenuous to cite, and perhaps his is a hypocritical ire to boot. The family's annual income exceeded $\$ 46,000$ and they admitted that they did not save for their daughter's education because they adopted her late in their lives (Berkey, 1993c). Not only did the family income surpass the grant program's Congressionally set ceiling of $\$ 42,000$ by $\$ 4,000$, the father was eligible for over $\$ 30,000$ in forgiveable federal education loans through the exclusive Perkins Loan Cancellation Program for law enforcement and correctional officers; a program not available to the average citizen. Thus while the average prisoner-student earns a skill related Associate degree costing less than $\$ 3,000$ in Pell Grants (Sarri, 1993), the irate cop can receive ten times as much federal money to improve his skills, advance his career, and raise his income at the public trough. The ironic aspect of these (supposedly antithetical) two taxfunded programs is that they both end up fighting crime.

Representative Holden's arguments against prisoner Pell Grant participation was based on the Pottstown Mercury's sensationalized series (Gauker, 1993), which in turn was substantially furnished with facts and figures from Congressman Gordon's office. Yet analysis of Gordon's objections still do not hold up. He complains that prisoners un- 
justly take a large number of grants away from traditional students, some schools unfairly provide, "prisoner-exclusive scholarships" that are not available to other students, no one tracks prisoners to see if they use their educations "properly" upon release, and other funds should be used to provide these opportunities so as not to unnecessarily duplicate government services.

During the original House debate over Amendment 1168, Gordon's side kick in that ignoble misadventure, Coleman, claimed 100,000 prisoners received Pell Grants each year (Congressional Record - House, 1992). It turned out to be an interesting statistic. It would have meant that one out of every 8 prisoners at the time (there were 800,000 prisoners in the United States during that year) were college students (Bureau of Justice Statistics, 1992), while just a few years earlier only one out of every one hundred prisoners had a college education (Greenfield, 1985). Now Gordon "estimated" that only half of the number cited by Coleman (50,000 prisoners) received Pell Grants totalling some \$200 million in funding (Berkey, 1993b). In the same breath, however, Coleman admitted that Pell awards for prisoners averaged only $\$ 1400$, which if multipled by 50,000 equals only $\$ 70$ million in funding. The ludicrousness of both sets of figures is that they bare no resemblance to reality.

In 1993, Lillis (1994) reported there were approximately 38,000 prisoner-college students in the nation while other studies (Berkey, 1993d; Sarri, 1993) revealed that at most 80 percent of these students received Pell Grants. In other words, at best just over 30,000 prisoners received Pell Grants in 1993 (Pell, 1994) at an average of $\$ 1,400$ per grant for approixmately $\$ 42$ million. Approximately six-tenths of 1 percent of the $\$ 6$ billion in Pell Grant funds distributed in 1993 went to prisoner-students; all told, far less than the 50,000 recipents and $\$ 200$ million in aid, cited by proponents of the exclusionary legislation.

The Representative was also critical of schools giving prisonerscholarships to cover the differential between the Pell Grant award and standard tuition schedules. Gordon believes that since these prisoner scholarships are not available to non-incarcerated students, they are discriminatory in nature (Berkey, 1993b). The schools that provide these in-house tuition stipends can do so because of the reduced costs involved in educational programs in the penal settings. Classrooms, utilities and maintenance are provided at no expense, and student services ranging 
Journal of Prisoners on Prisons, Vol. 8. No. 1 and 2, 1997

from marketing to counselling to placement are greatly reduced as well (Blumenstyk, 1991). If these scholarships were not provided, in many cases there would be no other way for prisoner-students to pay tuition, even reduced tuition, since they are excluded from even minimum wage jobs, barred from loan programs, and excluded from other grants and scholarships. And now the honorable representative from Tennessee objects to schools who are able to pass along their reduced expenses as student assistance in the process of lowered tuition charges.

A point consistently stressed by Gordon is that prisoners need to be tracked to see if higher education does indeed pay off upon their release (Berkey, 1993f). Never mind that no other Pell Grant recipients are tracked to see if they "properly" utilize their college educations; prisoners are a special class that must be continually tracked. Howard Petters III (1993), director of the Illinois Department of Corrections, emphatically states that, "statistics have proven that investing in correctional education reduces the likelihood of recidivism, enhances employability upon release and thus taxability, and even benefits the prison environment for all who live and work there.

Even with some mixed results, during the 1970s studies from New Jersey (Thomas, 1974), Alabama (Thompson, 1976), Maryland (Blackburn, 1979) and Pennsylvania (Blumenstein and Cohen, 1979) reported substantial reductions in recidivism rates amongst college students. During the 1980s, a plethora of evaluations from Texas (Gaither, 1980), Michigan (Haviland, 1982), New Mexico (Psychology Today, 1983), California (Chase and Dickover, 1983), Ohio (Holloway and Moke, 1986), Washington, D.C. (Lorton Prison College Program - Annual Report, 1990) and in Canada (Duguid, 1981) revealed either reduced recidivism rates or at least reductions in the seriousness of new offenses. By 1990, two massive studies of nearly one-thousand prisoner-students each were concluded in New York and Michigan. The New York Department of Correctional Services reported that earning a college degree while incarcerated was positively linked with successful post-release adjustment for students who completed the program (Clark, 1991). In the Michigan Department of Corrections - Jack Community College program, it was learned that not only were graduates, who were identified as, "some of the most hardened criminals to be found in the United States," returned to prison significantly less than the average convict, 
but when they did it was for less serious offenses (Wreford, 1990, p. 62).

Peter Drucker (1989) observes that in today's world, education, especially post-secondary education, is the major determinant of an individual's employability, career prospects and future. For decades it has been shown that there is a correlation between unemployment and dysfunctional behaviour including crime (Robinson, 1990), with unemployment itself being a significant contributor in parolee recidivism (Lawyer and Dertinger, 1993). Reports from New York (Wolf and Syles, 1981), Ohio (Holloway and Moke, 1986) and Canada (Duguid, 1981) during the recession of the early 1980 s found graduates of prison college programs were employed up to twice the rate of other ex-prisoners. The Pennsylvania Business Institute, which operates a program at the state's Graterford Correctional Facility, reported that of the 55 prisoner students released so far, only a few have returned and nearly all are employed (Berkey, 1993g).

A 1988 study concluded that society receives financial benefits of at least 12 percent on its total public and private investment in higher education (Bernstein and Magnusson, 1993). A recent National Bureau of Economic Research study reported that for each year of college a student completed, they earned 5 percent more than a high school graduate (Samuelson, 1992), and U.S. News and World Reports recently reported that over a working lifetime, a college graduate can expect to earn 1.9 times the likely earnings of a high school graduate (Zuckerman, 1995). Conservatively figuring a tax burden of 30 percent (Gergen, 1992), the prison college graduate more than pays for his incarceration and education just through taxation, not to mention law abiding behaviour as opposed to the norm of continued criminality.

As demands on governments exceed their fiscal capabilities, it is more necessary than ever before to invest in "smart" programs that not only reduce ever greater demands, but also add to the economic strength of the society. Over the years, several studies (Seashore, et al., 1976; Haber, 1983; Greenwood and Turner, 1985) have commented on the cost-savings that post-secondary correctional education programming can provide through reduced recidivism and increased taxation. My analysis of the possible cost-savings from increasing the number of paroled offenders with a college education to a level of 60 percent parity with the national rate of adults with a like amount of education (approxi- 
mately 25 percent), revealed cost-savings of non-incurred reincarceration costs of $\$ 120$ million annually (Taylor, 1992). Taking the model a step further, I found that by using two different crime-cost formulas, that the cost-savings to society of crime not committed by rehabilitated ex-offenders ranged from 2 to twenty billion dollars (Taylor, 1992). An IBM computer program called "Tax Users vs. Tax Generators" produced a report that only a 1.6 percent reduction in recidivism over a 15 year time span in Alabama would increase tax revenues from that subpopulation by 30 percent, while decreasing the demand for correctional spending by over 40 percent (Chancellor, 1992). Chris Marschner, the Hagerstown Junior Community College prison program coordinator, states simply that, "the rate of return on educating a prisoner is so great that [only] an idiot wouldn't do it" (Money, 1992). This is a comment that makes one wonder about those who backed the legislation to eliminate the funding for such opportunities.

A final objection by the Congressman to the use of the Pell Grant program by prisoners is that other federal programs offer rehabilitative training and literacy education, and, "mixing the roles of the federal student aid and prisoner rehabilitation leads to a wasteful service duplication" (Berkey, 1993g). As noted previously, the "other programs" that exist are grossly underfunded, limited in scope, and are not applicable to college programming. Furthermore, higher education is a highly efficient means to reduce offender recidivism. Without Pell Grant financing these opportunities simply cease to exist (Lohman, 1992). Senator Pell comments that he does, "believe prisoners should be able to use a Pell Grant to achieve a college education. Other programs are not the answer. They are very inadequately funded" (Berkey, 1993b). David Evans, Pell's staff director, scoffs at Gordon's suggestion to use other appropriations to fund the prison college programs. "I don't buy that answer," Evans says. "It's the way of getting out of it. Take the money from here and get it from somewhere else. There are no excesses of money at the federal level" (Berkey, 1993h).

Evans also disagrees with the assumption that prisoners deprive traditional students of Pell Grants. He claims prisoners are not doing so (Berkey, 1993h). Dr. Gary Rizzo, associate dean of Montgomery County Community College, who has been monitoring the school's prison program for a decade, is even more adamant in his objections to this assumption. "Those traditional students are taking money away 
from prisoners," Rizzo argues. "There's no compelling reason to deny [prisoners]. Their logic is flawed" (Berkey, 1993h).

Dr. Steven Steurer, the executive director of the Correctional Education Association and himself a prison teacher, openly wonders why correctional populations are continually treated so differently than the rest of society. In referring to the exclusion of whole state prison populations from Pell Grant eligibility because of the "states" violation of the supplant/supplement rule imposed by the 1992 Higher Education Reauthorization Action (HERA), Steurer observes that everywhere else students apply for Pell Grants at their colleges and are declared eligible if they meet the criteria. In his opinion, "the policy is rather inconsistent and, to say the least, unfair" (Steurer, 1993).

In the final measure, perhaps the strongest reason to allow prisoners Pell Grant eligibility comes from the simple words of a graduate of these programs. Commenting on earlier Congressional attempts to exclude prisoner grant participation, the ex-prisoner reflected that, "I would hate to think what would have happened to me if there was no college program while I was incarcerated - without it I would have joined the ranks of repeat offenders and become another addition to the escalting figures of recidivism" (Justice Watch, 1992).

The real issue behind the smokescreen thrown up to obscure the problem is not the relative infinitesimal use of Pell Grants by prisoners, rather it is the overall higher education funding crunch coupled with stagnant if not declining family incomes. The attack on prisoners receiving Pell Grants amounts to shopping around for scapegoats. As political analyst William Greider (1991) explains, it is, "a way to change the subject from what is really hurting people." So that, "whenever people are losing their jobs and social decline is visible, it's easier to blame the troubles" on minority segments who seem to be, "getting more than their share." The fact that politicians avoid addressing substantative issues with positive actions, leaves little wonder why a recent Gallup Poll found that law makers rank below lawyers and even talk-show hosts in public esteem (Wildstrom, 1993). The rogues gallery assembled, in effect, to perpetuate crime through assuring high rates of recidivism by 
denying prisoners access to Pell Grants is a classic example of the hypocrisy emanating from Washington in the guise of governance.

Very few of us would even think to question the lack of moral integrity possessed by prisoners; it seems to be a given. However, should we not at least question the political integrity of those obtusely promoting the exclusion of prisoners from Pell Grant assistance?

Senator Hutchinson represents the great state of Texas, which brought the nation the macabre spectacle of dueling gubernatorial candidates outbidding one another on the number of prisoners they would fry if elected (Minton, 1993), proposed state legislation to ship prisoners to China as a cost-savings measure, the perenial bill to punish thieves by cutting off their fingers (Parade Magazine, 1994), and 56 prisons currently under construction (Heines, 1994). From this wellspring of criminal justice philosophy, the senator not only voted for the most repressive and bloody (adding over 50 new death penalty crimes) legislation in U.S. history, but in addition proposed the elimination of funding for the most effective crime fighting program in corrections today. And all the while she was busy lethally injecting convicts and expelling prisoner-students in the senate, Hutchinson was battling her second indictment at home for misusing State property and employees to conduct personal business and political campaigning (Irvins, 1994). Perhaps it was the senator's alleged misappropriations of public funds that sensitized Hutchinson to what she myopically viewed as another theft on the public purse when she sponsored the prisoner Pell Grant ban. Hutchinson should be cautious, though, for some day she may need something to occupy her time when she is in one of those new Texas prisons.

Then we have everybody's favourite troglodyte, father of the prisoner Pell Grant exclusion and self-admitted bigot, Senator Jesse Helms, whose state of North Carolina outranks even Texas on the Justice Fellowship's Criminal Justice Crisis Index scale (Inside Journal, 1993). It was Helm's proclaimed concern over student college funding that supposedly prompted his original prisoner exclusion legislation; though, later, hypocritically, the senator cast the single vote against the Higher Education (Pell Grant) Reauthorization Act (Krauss, 1992). Even his past ghost-writer [Leonard, 1992], the conservative national columnist George Will (1994), recently considered the proposed funding ban and felt it was, "grandstanding and chest thumping," and came out in support of prisoners receiving Pell Grants. 
Another in the lineup was Representative Thomas Coleman from Missouri. This state shuttered all of its prison college programs early in 1994 because it had reduced its funding for prisoner education and treatment from 3.3 percent of its 1983 corrections budget (Ryan and Woodard, 1987) to only 1.2 percent of its 1993-94 budget (Corrections Compendium, 1993). The specific elimination of state funding for its post-secondary correctional education program triggered the 1992 HERA's supplant-supplement rule, which caused the entire state prison population to be declared ineligible for Pell Grant assistance as the state dropped below its 1988 prison higher education funding level as the Show-Me-State did. So as Coleman ludicrously fulminated about 100,000 prisoners receiving Pell Grants, he sent out 255,000 postcards to constituents at a cost in excess of $\$ 50,000$ proclaiming that he was outraged by the Congressional checking scandal, and, that he did not bounce a single draft (Insight, 1992). Pete Sepp of the National Taxpayers Union (NTU) commented that, "the money he spent on that would probably rival anything he could have bounced in the bank" (Insight, 1992). The NTU identified Coleman as among the top seven percent of the users of the Congressional frank (free postage), which cost the taxpayers $\$ 80$ million in 1992. Coleman defended his use of the franking privilege claiming the House Banking Scandal was the number one issue among his constituents, and, "the people of my district need to know their member of Congress still has integrity and didn't bounce any checks" (Insight, 1992). He also spent enough in the single mailing to furnish over 33 students with $\$ 1400$ in Pell Grants.

All in all, the near bumbling efforts of Hutchinson, Helms and Coleman pale beside the pernicious actions of Holden and Gordon in the debate. Though it is possible that Representative Timothy Holden's remarks on the House floor were made out of ignorance that does not lessen their deleterious effects including arousing the feelings of those who listened to him because of the erroneous information he conveyed. Regurgitating and misrepresenting the information reported in the Mercury series, Holden cited a litany of abuses ranging from schoolbased fraud to inadequate oversight of the grant programs, to "lifers" receiving free college educations (Berkey, 1993a). The Congressman's ire was not only misplaced, but exposed either his lack of reading comprehension, knee-jerk reactionism, or deliberate misrepresentation of the facts. 
Abuses of the Pell Grant program were sadly rather common during the tenure of the Reagan administration. More than 1,600 schools (mostly fly-by-night trade schools teaching skills such as cooking and trucking (Foust, 1993)) have been closed during a recent two-year Department of Education fraud investigation (Berkey, 1993f). Focusing on corrections, only a handful of propriety schools with prisoners composing 100 percent of their enrollments were found to be guilty of abuses. These abuses ranged from charging prisoner-students for room and board to filing claims for non-existent students. Meanwhile, some three dozen ultra-orthodox Jewish seminaries in the New York area alone were accused of illegally bilking the Pell Grant program for as much as $\$ 40$ million (Fenyvsi, 1993); more than the annual total disbursements to prisoner-students. Yet, no one was calling for the banishment of would-be cooks, truckers or rabbis from the Pell Grant program for what their schools did, only prisoners.

The allegations of the DOE's Office of Post-Secondary Education (OSPE) of mismanagement of the federal grant and loan programs are reasonable charges. Instances of store front schols, non-resident students, and non-enrolled students receiving. millions of dollars in aid supported the mismanagement charges. However, this is another legacy of Reagan staffing cuts that left only 3 administrators to police 800 schools in the southwest (Toch, 1993), for example. To accuse the DOE of negligence in administering student aid programs is the same as berating the wheelchair basketball league for not having a team in the NCAA's Final Four. In none of these "fixes" to the Pell Grant program are there DOE-OSPE staffing increases. So even with the more stringent regulations that helped to convict the fraudulent schools the department will still occasionally drop the ball.

The really insidious, inflamatory charge made by Holden was that prisoners on death row and serving life without parole sentences were receiving free (i.e. worthless) college degrees. This simply was no longer the case and Holden knew it if he actually read the newspaper story he waved above his head. The 1992 legislation took a number of steps to rectify existing problems in the Pell Grant program relating to prison education. Besides the discriminatory supplant/supplement rules, housing allowances were eliminated from prisoner grants, only one-quarter of a school's enrollment could be prisoners (although a waiver could be granted to non-profit degree granting institutions) and the political con- 
cession was made that death row and life without parole prisoners were ineligible for grants (CURE, 1992). By the time Holden pontificated before the C-SPAN cameras, the "abuses" he cited out of ignorance or spite to antagonize a membership terrified of being seen as "soft on crime" had been a moot point for over a year.

Representative Bart Gordon, though, is by far the worst offender in not only the misinformation campaign, but in essentially promoting a racist agenda. Since the introduction of his Amendment 1168, the Congressman has been furnished with numerous evaluation studies and reports (including many of those cited here) detailing the effectiveness of post-secondary correctional education programs in significantly reducing participants' costly and painful cycle of recidivating through the system time and time again. His continued objection to prisoner Pell Grant funding because no one has tracked Pell Grant funded prisonerstudents' post-release behaviour is a totally disingenuous allegation. No matter where the financing originates, it is the education, not the dollars that pay for it, that effects the change in the students. Ignoring numerous studies by the representative, some of which indeed noted Pell Grant financing, is particularly obstreperous. Along with the myriad of other erroneous "facts" cited by Gordon, his credibility on the issue, to say the least, is suspect.

Finally, Charles Sullivan, the executive director of the Citizens United for the Rehabilitation of Errants public interest group, explains that Gordon's legislation smacks of racism since the majority of the penal population is composed of minorities (Berkey, 1993I), and thus minority groups will be disproportionately affected by banning the Pell Grants for prisoners. In fact, several studies (Blumenstein and Cohen, 1979; Haviland, 1982; Holloway and Moke, 1986; Wreford, 1990) have noted that post-secondary correctional education enrollments largely reflect the ethnic composition of prisons. Beverley Coles, director of education and housing for the NAACP, observes that the higher education shortfall has made college education increasingly inaccessible for African-American students, 85 percent of whom receive some type of aid (Del Valle, 1992). And with more young black males in prison than on college campuses (Maurer, 1990), Sullivan (1991) wonders, as absurd as the concept is, about having to go to prison to receive a college education, are we now going to close that avenue off, as well? 
Lillis (1993b) in the Corrections Compendium, comments on financing correctional education. She points out that "voters and legislators around the country must choose between inmate rehabilitation or inmate recidivism." By playing to the "cheap seats" in the rhetoric of getting tough on crime and fighting government waste, the advocates for excluding prisoners from Pell Grant participation are only exacerbating the agony perpetuated by the continued criminalization, victimization and reincarceration plaguing our society.

In the final analysis, piercing the fog of how many grants, how much money, how else to fund, etcetera, the elimination of prisoner Pell Grant eligibility effects the closure of post-secondary correctional education opportunities in the United States. Questioning the wisdom of the ban when it was still a proposal, Fernando Garcia, a 21 year-old prisoner at the Camp Hill Penitentiary in Pennsylvania, wondered, "Why stop me from becoming a better person?" (Berkey, 1993f). With all the factors considered, "Why indeed?"

\section{REFERENCES}

Associated Press (1992). "Pell Grants Ran Over Budget." (August 25).

Austin, A. \& Irwin, J. (1990). Who Goes to Prison? San Francisco, CA: National Council on Crime and Delinquency.

Barker, E. (1986). "The Liberal Arts in the Correctional Setting: 'Education Befitting Free Men' -- For Those Who Presently Are Not Free," Presented at the Correctional Education Association Conference, Cincinnati, $\mathrm{OH}$.

Bell, R., Conrad, E., Laffey, T. Lutz, J., Miller, P., Simon, C., Stakelon, A. \& Wlson, H. (1979). Correctional Education Programs for Inmates. U.S. Department of Justice, Washington, D.C.

Bell, R., Conrad, E. \& Suppa, R. (1984). "Findings and Recommendations of the National Study on Learning Deficiencies in Adult Inmates," Journal of Correctional Education, V. 35, N.4:129-137.

Berkey, K. (1993A). "Holden Takes Articles to the House Floor," The Mercury, (October 28): Al, A4.

Berkey, K. (1993B). "College Grants Meant for Students go to Cons," The Mercury, (October 24): Al, A4.

Berkey, K. (1993C) "Policeman's Daughter can't get Pell Grant," The Mercury, (October 26): A1, A4.

Berkey, K. (1993D). "Inmates learn - the Hardway," The Mercury, (October 25): A5.

Berkey, K. (1993E). "More Pa. Jails, More Pell Grants," The Mercury, (October 25): Al, A4.

Berkey, K. (1993F). "Commit Murder, Go to College," The Mercury, (October 27): Al, A4. 
Berkey, K. (1993G). "P.B.I.: Pottstown, Prison Business Institute," The Mercury, (October 25): A1, A4.

Berkey, K. (1993H). "Pell Grants Never Meant for Inmates," The Mercury, (October 24): A1, A5.

Berkey, K. (1993I). "Drugs Led to Prison \& College," The Mercury, (October 26): A1, A5.

Bernstein, A. (1991). "Is Uncle Sam Shortchanging Young Americans," Business Week, (August 19): 85.

Bernstein, A. (1993A). "The Young and the Jobless," Business Week, (August 16): 107.

Bernstein, A. \& Magnusson, P. (1933). "How Much Good Will Training Do?" Business Week, (February 22): 76-77.

Bureau of Justice Statistics (1992). "Bureau of Justice Statistics: National Update," U.S. Department of Justice (January) V.1, N3.

Blackburn, F. (1979). The Relationship Between Recidivism and Participation in Community College Associate of Arts Degree Program for Incarcerated Offenders. Ed.D. Dissertation, Virginia Polytechnic Institute and State University.

Blumenstein, A. \& Cohen, J. (1979). "Control of Selection Effects in the Evaluation of Social Problems," Evaluation Quarterly, V. 3, N. 4:583-608.

Blumenstyk, G. (1991). "Use of Pell Grants to Educate Inmates Provokes Criticism," The Chronicle of Higher Education, (June 5): Al, A 20.

Cauchon, D. (1992). "Lock ‘em up' Policy Under Attack," USA Today, (September 1).

Chancelor, F. (1992). A Study of Alabama Prison Recividism Rates of those Inmates having Completed Vocational and Academic Programs while Incarcerated Between the Years of 1987 thru 1991. A special report by the Department of Post-Secondary Education, Alabama Department of Corrections.

Clark, P. (1991). Analysis of Return Rates of the Inmate Program Participants. Albany, NY: New York Department of Correctional Services.

Clark, R. (1970). Crime in America. New York: Simon \& Schuster.

Congressional Record-House (1992A). "Amendment Offered by Mr. Coleman of Missouri," (March 26): 1892-98.

Congressional Record-Senate (1992). "Higher Education Amendments," (February 21): 1947-1969.

Congressional Record-Senate (1993). "Amendment No. 1158," (November 16): 15746.

Conrad, J. (1981) Adult Offender Education Program. Cambridge, MA: Abt Associates, Inc.

Corcoran, F. (1985). "Pedagogy in Prison: Teaching in Maximum Security Institutions," Communications Education, V. 34, I.1:49-58.

CURE Newsletter (1992). "Prisoners will CONTINUE to Receive Pell Grants," (Summer): 1.

Currie, E. (1994). "What's Wrong With the Crime Bill," The Nation (January 31): 118-121.

Cutler, B. (1989). "Up the Down Staircase," American Demographics, (April): 32-41. 
Del Valle, C., Schine, E. \& McWilliams, G. (1992). “A Lot Less Moola-Moola On Campus," Business Week, (October 5): 114-115.

Drucker, P. (1989). "How Schools Must Change," Psychology Today, (May): 18-20.

Duguid, S. (1981). "Rehabilitation Through Education: A Canadian Model," in Lucian Morain (ed.) On Prison Education. Ottawa, Canada: Canadian Publishing Centre.

Farrell, C. (1993). "Time to Prune the Ivy," Business Week, (May 24): 112-118.

Fenyvesi, C. (1993). "Washington Whispers: Tuition Fraud," U.S. News \& World Report, (September 27): 21.

Foust, D. (1993). "Student Loans Ain’t Broke. Don’t Fix ‘Em," Business Week, (April 5): 74.

Gauker, J. (1993). “Irresponsible Pell Grant/Prisoner Sensationalism," Graterfriends, V. 11, N. 8:1.

Gergen, D. (1992). "Welcome to Great Society II," U.S. News \& World Report, (August 1): 42.

Greenfeld, L. (1985). "Examining Recidivism," U.S. Department of Justice, Bureau of Justice Statistics.

Gaither, C. (1980).“An Evaluation of the Texas Department of Corrections' Junior College Program," Huntsville, TX: Department of Correction Treatment Directorate, Research and Development Division.

Greenwood, D. \& Turner, S. (1985). The Vision Quest Program: An Evaluation. Santa Monica, CA: Rand Corporation.

Greider, W. (1991). "The Politics of Diversion, Blame It on the Blacks," Rolling Stone, (September 5): 32, 33, 96.

Haber, G. (1983). "The Realization of Potential by Lorton, D.C. Inmates with UDC Education Compared to Those Without UDC Education," Journal of Offender Services, Counseling and Rehabilitation, 7: 37-55.

Haviland, J. (1982). A Study of the Differences Between Prison College Graduates and the Total Released Inmate Population on Recidivism by Risk Category. Unpublished Doctoral Dissertation, Western Michigan University.

Heins, V. (1994). "Governor Helps Break Ground for San Diego Prison," The CallerTimes (February 26).

Hitchens, C. (1993). "Minority Report," The Nation (August 9/16): 164.

Holloway, J. \& Moke, P. (1986). Post-Secondary Correctional Education: An Evaluation of Parole Performance. Wilmington, $\mathrm{OH}$ : Wilmington College.

Horvath, G. (1982). "Issues in Correctional Education: A Conundrum of Conflict," Journal of Correctional Education, 33: 8-15.

Hutchison, K. (1994). "Should Inmates Get Student Aid? NO: Deserving Pupils Lose Out on Pell Grants," USA Today (March 17): 13A.

Innes, C. (1988). "Profile of Inmates 1986, Special Report," U.S. Department of Justice, Bureau of Justice Statistics: NCJ-109926.

Inside Joumal (1993). "Criminal Justice Crisis Index Compares States," (Nov/Dec): $1,3$.

Insight (1992). "Frank Words," (June 1): 29.

Ivins, M. (1994). "My Friends, the Time is Not Yet," The Nation (February 7): 159161. 
Justice Watch (1992). "From a Concerned Citizen," (Spring): 4.

Koretz, G. (1993). "Community College Educations Pay Off in the Labor Market," Business Week, (May 24): 22.

Kozol, J. (1985). Illiterate America. New York, NY: Anchor Press.

Krammer, M. (1993). "Clinton's Drug Policy Is a Bust," Time (December 20): 35.

Krauss, C. (1992). "Senate Votes to Expand Aid to Needy College Students," New York Times (February 22): 6.

Leonard, J. (1994). "Our Life and Times," The Nation, (February 21): 238-242.

Lillis, J. (1993A). "DOC Budget Nearly \$22 Billion," Corrections Compendium, V. 18, N. 9: (September): 7, 10.

Lillis, J. (1993B). "Cutbacks May Endanger Inmate Education," Corrections Compendium, V. 18, N. 9 (September): 14.

Lillis, J. (1994). "Prison Education Programs Reduced," Corrections Compendium, V. 19, N. 3 (March): $1-4$.

Lawyer, H. \& Pertinger, T. (1993). "Back to School or Back to Jail?" Criminal Justice (Winter): 21, 51-52.

Lorton Prison College Program -- Annual Report, (1990). Division of Continuing Education, University of the District of Columbia, (November).

Mauer, M. (1990). "The Sentencing Project Receives National Attention," The Sentencing Project, (Summer).

McNamee, M. (1994). "Robert's Rules of Order," Business Week, (January 24): 7475.

Minton, J. (1993). "Crime Prevention Keys Lies in the Next Generation," The Advocate, (January 19).

Money, J. (1992). "Pell Grant Bill May End Prison Programs," Hagerstown Morning, (Apriil 1): A-1.

Parade Magazine (1994). "The Best \& Worst of Everything," (January 2): 5.

Parlett, T. (1981). "The Benefits of Advanced Education in Prison," in Lucian Morain (ed.), On Prison Education. Ottawa, Canada: Canadian Publishing Centre.

Pell, C. (1994). "Should Prisoner Get Student Aid? Yes: Pell Grants Dramatically Reduce Recidivism," USA Today, (March 17): 13A.

Perkins, C. (1993). National Corrections Reporting Program, 1990. Bureau of Justice Statistics, U.S. Department of Justice, (May).

Peters, H. (1993). "Letter to Members of the International Correctional Association," Illinois Department of Corrections (April 13).

Psychology Today (1983). "Learning Maketh an Honest Man," (April): 77.

Quay, H. (1973). "What Corrections Can Correct and How," Federal Probation, (June).

Quinn, J. (1992). "The New Rules for College Aid," Newsweek (September 21): 74.

Robinson, W., et al. (1990). Prison Populations Cost Illustrative Projections, 1980. Washington, D.C. G.P.O.

Ryan, T. \& Woodard, J. (1987). Correctional Education: A State of the Art Analysis. National Institute of Corrections, (July 7).

Samuelson, R. (1992). "The Value of College," Newsweek (August 31): 75.

Sanders, B. (1993). "Clinton Must Go to the People," The Nation, (June 21): 865-867. 
Sarri, R. (1993). "Educational Programs in the State Department of Corrections: A Survey of the States," Paper presented at the American Society of Criminology, Phoenix, AZ, (November).

Schwart, G. \& Koch, C. (1992).“U.S. Department of Education's Correctional Initiatives," Issues in Teacher Education, V. 1, N. 2:100-108.

Spillane, M. \& Shapiro, B. (1992)."A Small Circle of Friends," The Nation, (September 21): 278-281.

Stephan, J. (1992).Census of State and Federal Correctional Facilities, 1990. Bureau of Justice Statistics, U.S. Department of Justice (May): NCJ-137003.

Steurer, S. (1993). "Legislative Accomplishments," CEA News \& Notes, V. 15, N. 3, (July): 6.

Sullivan, C. (1991). "Correspondence: Dear Board Members," CURE (August).

Sullivan (1994). "FACT SHEET." CURE.

Taylor, J. (1992). "Post-Secondary Correctional Education: An Evaluation of Effectiveness and Efficiency," Journal of Correctional Education, V. 43, I. 3, (September): 132-141.

Taylor, J. (1993A). "Pell Grants for Prisoners," The Nation, (January 25): 88-91.

Taylor, J. (1993B). “Déjà Vu All Over Again,” Indiana Defender, (September): 23.

Taylor, J. (1994). "Should Prisoners Have Access to Collegiate Education? A Policy Issue," Educational Policy V. 8, N. 3 (September): 315-338.

The Washington Spectator (1992). "FYI, Items of Interest from Spectator Files," V. 18 , N. 20 (November): 4.

Thomas, F. (1974). "Narrative Evaluation Report on the Institute for Educational Media Technology," Burlington County Collect, NJ.

Thompson, J. (1976). Report on Follow-up Evaluation Survey of Former Inmate Students of Alexander City State Junior College. Alexander City State Junior College, AL (July).

Toch, T. \& Slafsky, T. (1991). "The Great College Tumble," U.S. News World Report, (June 3): 50.

Wagner, B. (1993). "The High Cost of Learning," U.S. News \& World Report (June 21): 58.

Wildstrom, S. (1993). "Washington is Becoming a City of Amateurs," Business Week, (October 11): 42.

Will, G. (1994). "Prisoners, Pell Grants and Public Safety," Washington Writers Group, (January 31).

Wolf, J. \& Wylves, D. (1981). The Impact of Higher Education Opportunity Programs: Post Prison Experience of Disadvantaged Students: A Preliminary Follow-up of HEOP Ex-offenders. Albany, NY.

Workforce 2000: Work and Workers in the 21st Century. Hudson Institute, Indianapolis, $\mathbb{I N}$.

Wreford, P. (1990). Community College Prison Program Graduation and Recidivism. Unpublished Doctoral Dissertation, University of Michigan. 